\section{СВИДЕТЕЛЯТ (разказ)}

Напоследък непрекъснато се явяваше пред погледа ѝ. Непрекъснато ѝ напомняше за себе си, сякаш я търсеше по важна работа.

Беше кухненски нож. Средно голям, много остър. Стилна черна дръжка, шведска стомана. Беше предизвиквал сълзи в очите й, когато режеше лук с него. Тогава тя чувстваше, че ѝ се извинява за сълзите, които й причинява. Най-много обичаше да режат краставици на колелца заедно. И той като нея никак не обичаше да реже месо. Преди това го точеше с чувство на вина, че отнема част от него. Той се подчиняваше на необходимостта, защото беше мъдър. Не ѝ беше изневерил досега, помагаше ѝ, а и тя се грижеше за него. Имаха специални отношения. Когато режеха заедно ябълки, се променяше. Ставаше ароматен и свеж. Да, заедно режеха. Заедно. Никога не бяха правили нещо с мъжа си заедно. Дори когато правеха децата си, всеки оставаше сам със себе си.

Ножът я гледаше от масата, когато се срути първата стена на дома. След тишината на срутването къщата им се оголи за чужди погледи и безсрамно изложи на показ дългогодишните й и, както се оказа - безплодни усилия да съгради истински дом.

Вятърът, който нахлу в дома им, издухваше смисъла на всичко. Един въпрос летеше като сух есенен лист, лепеше се по всички предмети и крещеше: защо?

Рухналата стена беше от жени, различни жени, с които беше живял, докато уж живееше с нея. Посредствени жени, на чийто фон се беше чувствал значим, докато пред нея изглеждаше блед и жалък - един направо безличен образ, на който се бе опитвала да придаде поне някаква външна форма.

Луксозната мебелировка, изисканите предмети, картините - всичко материално стана излишно в зейналото и грозно като отходна яма пространство на бившия дом. Нямаше какво да ги задържи и осмисли. Нямаше никакви общи спомени, нито чувство на заедност, а вероятната споделеност на живота им се разпръсна наоколо и изчезна без следа.
Когато въпросът стигна до ножа, не го попита нищо, само го погледна. И ножът стана свидетел на срутването на годините живот, уж преживяни заедно, а когато погледът ѝ се задържа върху него, за първи път видя острието му да се обагря в червено. Отклони поглед, реши, че е от стреса.

Дълго се дави от праха на облака, който остана на мястото на срутената стена и отрови дробовете ѝ. Едва дишаше, когато реши да събере някакви парчета и да се опита да възстанови стената, макар и да знаеше, че чуждите погледи завинаги ще си останат вътре в дома им и ще я преследват, сякаш престъпникът е тя.

Поживяха така още известно време - до онзи телефонен разговор, чут от нея случайно и поразил я с нежните звуци, които се оказа, че гласът му можел да издава. Тя никога не ги беше чувала. Нито тя, нито децата им. Тогава разбра, че се срутва втора стена. Покривът не можеше да се крепи на две стени и рухна. Над нея зейна заплашително небето, а вътре в нея имаше само едно голямо и празно, но болезнено пространство.

Истината се търкаляше надолу като малки камъчета по сипей, всеки ден по малко, докато отдолу не се появи скалата, върху която вече нищо не можеше да се задържи. Беше твърда, гола, безплодна и безсмислена.

Осъзнава я дни наред, оплетена в мъглата на яснотата, отчаянието и омерзението, когато в полезрението й се появи цветно петно.

Ножът пак беше започнал да се обагря в червено. Потапяше го задълго във вода и го търкаше до блясък, той също се стараеше, сътрудничеше, беше готов да бъде всичко, което искаха от него, но след няколко дни кървавите сълзи избиваха пак по острието му и пурпурният цвят се набиваше в очите ѝ отново.

Не, не беше само свидетел. С него бяха едно цяло. Защо го беше оставяла да бъде само свидетел? Той беше участвал в живота й много повече, отколкото всеки друг. Беше го пренебрегвала съвсем незаслужено. Никой в този дом не ѝ беше толкова близък.

Потопи го дълбоко в себе си с много обич и отдаденост, усмихна се на болката от любовта му и притвори очи.

$$
* *
$$

Д. Давидова
За афективните деформации на мисленето по съдържание

Човешкото мислене се разгръща на фона на емоции (и афекти), които са в състояние да му въздействат, да го стимулират към разкриване на истината, или, напротив - да деформират неговото съдържание, като го отклоняват от разкриването и познанието на истината.

... В психопатологията разстройствата на мисленето по съдържание, които възникват при участието или под „напора“ на силни емоции и афекти, се разпределят в три групи: свръхщенни идеи; натрапливи идеи; налудни идеи.

... Свръхценните идеи са грешки на съждението и умозаключенията, към които липсва критично отношение. То обаче може да се постигне чрез разубеждаване, т.е. след като на свръхценната идея се противопоставят доводи на разума и данни на опита.

Натрапливите идеи са грешки на съжденията и умозаключенията, към които поначало съществува критично отношение, но от които завладяваният от тях не е в състояние да се освободи.

Налудните идеи са също грешки на съжденията и умозаключенията, към които обаче болният няма критично отношение и в които не може да бъде разубеден с доводи на разума и данни на опита. Както казва една поговорка, „Сто мъдреци не могат да разубедят един луд, но един луд понякога може да убеди сто мъдреци“.

... Съществената разлика между налудното и свръхценното мислене, от една страна, и натрапливото, от друга, идва от това, че в първите два случая (при налудообразуването и при формирането на свръхценни идеи) емоционалният „натиск“ води до безкритичност, докато при натрапливостта изброените механизми остават като мъчителни тенденции, но критичността по принцип се запазва.

Коста Заимов, „Афективни параадаптивни реакиии на тичността”, изд. Мед. и физк., 1988 